\title{
Black Fungus an Escalating Threat for Covid-19 Patients Calling Out Captivation
}

\author{
Humaira Zafar*1, Irfan Ali Mirza², Dr Wajid Hussain³, Dr Muhammad Fayyaz \\ ${ }^{1}$ Professor of Pathology, Consultant Microbiologist, Al Nafees Medical College \& Hospital, Islamabad. \\ ${ }^{2}$ Head Department of Microbiology, Consultant Microbiologist, Armed forces Institute of Pathology, Rawalpindi. \\ ${ }^{3}$ Assistant Professor of Pathology, Consultant Microbiologist,Armed forces Institute of Pathology, Rawalpindi \\ ${ }^{4}$ Assistant Professor of Pathology, Consultant Microbiologist,Armed forces Institute of Cardiology, Rawalpindi
}

*Corresponding Author: Humaira Zafar, Professor of Pathology, Consultant Microbiologist, Al Nafees Medical College \& Hospital, Islamabad.

Received date: June 18, 2021; Accepted date: July 22, 2021; Published date: August 20, 2021

Citation: H Zafar, I A Mirza, W Hussain, M Fayyaz. (2021) Black Fungus an Escalating Threat for Covid-19 Patients Calling out Captivation. Clinical Research and Clinical Trials. 4(2); DOI: 10.31579/2693-4779/053

Copyright: () 2021 Humaira Zafar. This is an open access article distributed under the Creative Commons Attribution License, which permits unrestricted use, distribution, and reproduction in any medium, provided the original work is properly cited.

\begin{abstract}
Background: Current year 2021, brought a hope for the world due to availability of various vaccines to prevent COVID 19 . Researchers around the Globe, kept working around the clock to dig up various correlations of this infection. So, that morbidity and mortality rates can be reduced. In all this sprint, cases of black fungus came into light in India. The Indian researchers identified strong association of black fungus co infection in COVID patients resulting in high mortality rates.
\end{abstract}

Objectives: Therefore, this current systematic review was planned to identify the predisposing factors, clinical presentations and management options for black fungus in COVID 19 patients.

Methodology: This 'systematic review' was carried out following preferred reporting items for systematic review and metaanalysis (PRISMA) guidelines \& various search engines. Total 20(N) articles were selected and included for study. After following PRISMA guidelines and based upon inclusion and exclusion criteria of study, total $05(\mathrm{~N})$ manuscripts, were included.

Results: Out of 05(N) selected articles, $80 \%$ ( 04) strongly supported strong association of black fungus with COVID 19 patients. The highlighted predisposing factors includes, immunosuppression, anti virals, prolong hospital stay, use of tocilizumab and steroids as management of COVID patients. Timely diagnosis and provision of anti-fungal can be helpful to reduce mortality form this co infection.

Conclusion: It is concluded that immunosuppression, anti virals, prolong hospital stay, use of tocilizumab and steroids as management of COVID predisposes to black fungus. Timely diagnosis and use of systematic anti fungals can reduce mortality rate form this co infection.

Keywords: black fungus; mucormycosis, covid 19; immunosuppression; anti virals; prolong hospital stay; use of tocilizumab; steroids; systemic anti-fungal

\section{Introduction}

In the year 2019, emergence of COVID 19 called a hue and cry around the Globe. Absence of specific management and non-availability of vaccination kept on adding to the miseries of patients. Current year 2021, brought a hope for the world due to availability of various vaccines to prevent COVID 19. Researchers around the Globe, kept working around the clock to dig up various correlations of this infection. So, that morbidity and mortality rates can be reduced. Despite the passage of more than 1.5 years, many mysteries of this infection are yet to be discovered.
In all this sprint, cases of black fungus came into light in India. The Indian researchers identified strong association of black fungus co infection in COVID patients resulting in high mortality rates. The black fungus is also well known by a name of Mucormycosis. This supports many globally conducted studies which clinched that Corona virus infects the persons having weakened immune system. So, in current pandemic situation, due care should be taken to improve personal immunity. This can be achieved by taking healthy and balanced diet, exercise, along with good sleep and adoption of stress free life style. This will be a simple solution to get ourselves saved from acquiring this infection [1]. 
Immunodeficiency can be the result of either primary or secondary causes. The primary immunodeficiency is usually present at birth, while secondary is the one acquired during the passage of life. There can be many causes of secondary immunodeficiency like malnutrition, extreme of ages, prolong debilitated illnesses, complicated surgeries or any other illnesses requiring prolonged hospital stay especially in intensive care units (ICUs), and organ transplantation. Uncontrolled diabetes, cancers, use of steroids, chemotherapeutic drugs, intra venous drug abusers, and Human immunodeficiency viral infection are other added causes. Even the exhaustive, hectic routines, extreme work pressure, hidden stresses of daily life etc all can be the triggering factors for immunodeficiency. Moreover, depending upon the underlying condition, it can be mild to severe in intensity. Hence, the decision for management depends upon the cause and severity of signs and symptoms [2].

The latest available data highlighted predisposing factors includes, immunosuppression, anti virals, prolong hospital stay, use of tocilizumab and steroids as management of COVID patients [3]. Timely diagnosis and provision of anti-fungal can be helpful to reduce mortality form this co infection [4].

In view of existing hue and cry for co-existing black fungus worsening COVID 19 scenario, thi systematic review was planned. The objectives were to identify the predisposing factors, clinical presentations and management options for black fungus in COVID 19 patients.

\section{Materials and Methods}

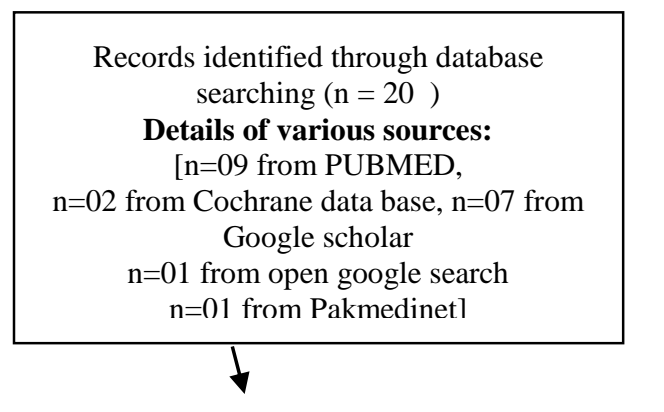

This systematic review was carried out by PRISMA guidelines - 2019 [5]. Total 24 studies were selected and included for study. The search was carried out in four stages i.e identification, screening, eligibility and final included ones. The details are shown in figure- I.

Certain MESH key words were used for searching the relevant literature review. These key words were Black fungus, COVID 19, immunosuppression, anti virals, prolong hospital stay, use of tocilizumab, steroids, systemic anti-fungal. The meta-analysis, systematic review, original articles, review articles and guidelines published in impact factor journals in last 05 years were included. While amongst all these the ones having details for symptoms of COVID in any age group, with or without symptoms of black fungus/mucormycosis were included. However, editorials, letter to editor, case reports, commentary, case series report and short communications were excluded.

Twenty four studies $(n=24)$ were included for the systematic review. Out of 20 (n), 09 (n) were from selected from PUBMED, 02 (n) from Cochrane Data Base, 07 (n) from Google scholar, 01 (n) from open google search and 01 (n) was selected from PakMedinet. 04 (n) articles were selected by snowball method form one meta-analysis. This is shown in figure 1. For standardization of selected articles, critical appraisal was done for finally selected $05(\mathrm{~N})$ articles. Out of them, 02 were review articles, o1 was systematic review, one was meta-analysis and 01 was original article. The salient points for 05 selected articles is shown in table I
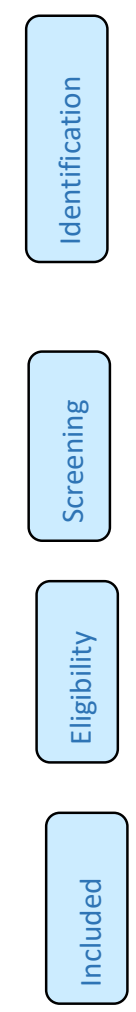

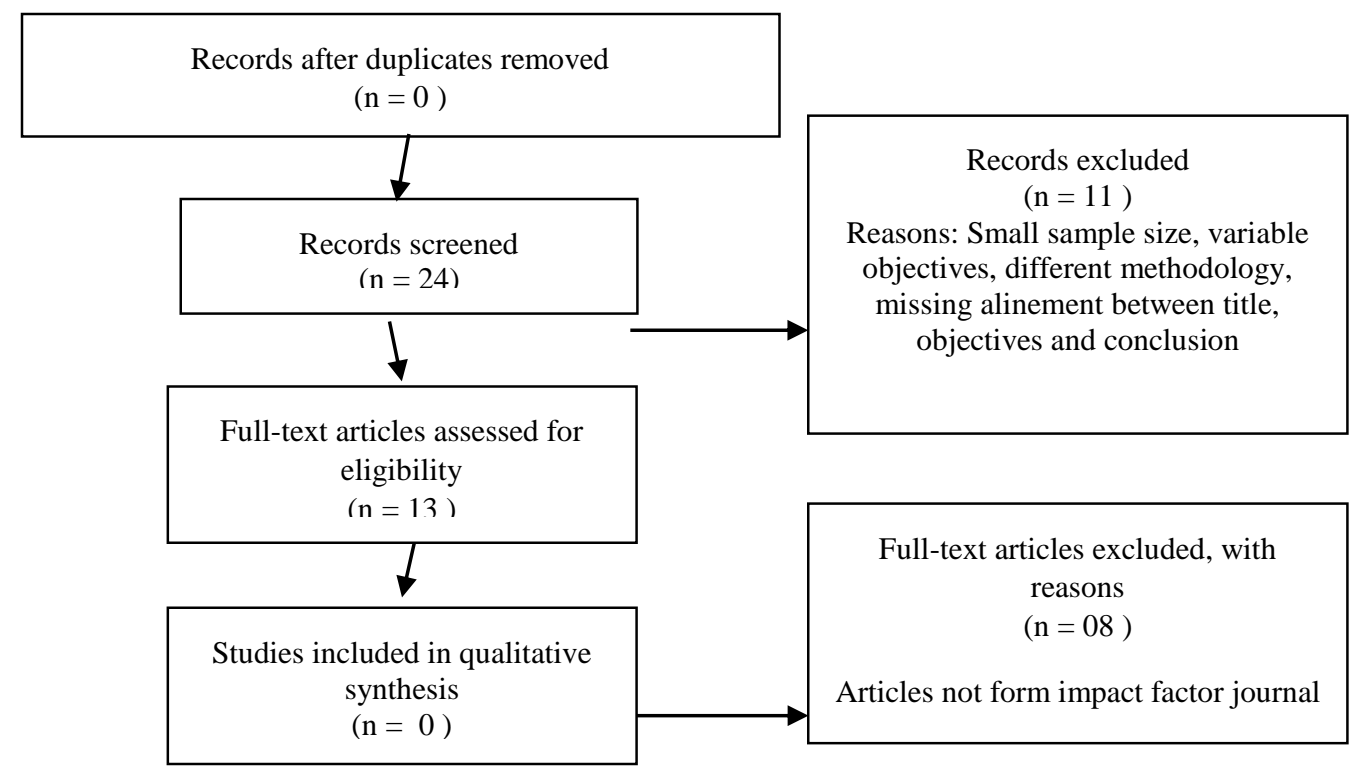

Studies included in quantitative synthesis (meta-analysis) $(\mathbf{N}=\mathbf{0 5})$ 


\section{Results:}

The salient results extracted from the critical appraisal of 05 selected articles are shown in table I. It was identified that, the estimated prevalence of black fungus / Mucormycosis is 2-6\%. Amongst which Rhizopus, Mucor and Lichtheimia are responsible ones i.e $34 \%$ cases and $19 \%$ for other two. The moratlity rate is between $50 \%-80 \%$.

A strong association of black fungus in COVID patients is due to immunodeficiency, decreased cluster of differentiation 4 and 8 positive T-helper (CD4+ T and CD8+ T) cell counts, prolonged hospital especially intensive care units (ICUs) stay. Further added factors are necessisitity of mechanical ventilation i.e nasal/face mask or ventilator support, use of glucocorticoids, use of potent anti-inflammatory and anti-viral drugs. These all predisposing factors are in line with certain other predisposing factors for emergence of serious and fatal co infections. It was also clinched that Fungal cultures, direct staining of sample, Enzyme Linked Immunosorbent Assays (ELISA), and PCR can be used for diagnosis of mucormycosis. While Combination of systemic anti fungals and surgical debridement can improve treatment outcomes. Besides this intraorbital irrigation with amphotericin will be helpful for spreading craniofacial infection. All these are shown in table I.

\section{Discussion:}

\begin{tabular}{|c|c|c|c|}
\hline Studies included & $\begin{array}{l}\text { Type of } \\
\text { studies }\end{array}$ & Conclusion & Reason for selection \\
\hline $\begin{array}{c}\text { Skiada A, Floerl CL, Klimko N, Ibrahim } \\
\text { A, Roilides E, Petrikkos G, etal. } \\
\text { Challenges in the diagnosis and } \\
\text { treatment of mucormycosis. Med } \\
\text { Mycol. 2018; 56(1): } 93-101 . \text { Doi: } \\
\text { 10.1093/mmy/myx101 }\end{array}$ & $\begin{array}{l}\text { Meta- } \\
\text { analysis }\end{array}$ & $\begin{array}{l}\text { Prevalence of black fungus / Mucormycosis is } 2-6 \% \\
\text { - } 34 \% \text { cases Rhizopus species, and } 19 \% \text { for both } \\
\text { Mucor and Lichtheimia species are responsible for } \\
\text { mucormycosis. . } \\
\text { - Mortality rate showed a range of } 50 \%-80 \%\end{array}$ & $\begin{array}{l}\text { Prevalence \& frequency of } \\
\text { mucormycosis is } \\
\text { highlighted }\end{array}$ \\
\hline $\begin{array}{l}\text { 2. Khatri A, Chang KM, Berlinrut I, } \\
\text { Wallach F. Mucormycosis after } \\
\text { Coronavirus disease } 2019 \text { infection in a } \\
\text { heart transplant recipient -review of } \\
\text { literature. J Mycol Med. 2021; 31(2): } \\
\text { 101125. Doi: } \\
\text { 10.1016/j.mycmed.2021.101125 }\end{array}$ & $\begin{array}{l}\text { Review } \\
\text { article }\end{array}$ & $\begin{array}{l}\text { COVID is usually involved immunodeficient host i.e } \\
\text { decline in cluster of differentiation } 4 \text { and } 8 \text { positive } \\
\text { T-helper (CD4+ T and CD } 8+T \text { ) cell counts. } \\
\text { Immunosuppression in COVID predisposes to many } \\
\text { other infections. } \\
\text { While super added factors includes prolong hospital } \\
\quad \& \text { intensive care units (ICUs) stay } \\
\text { - Necessity of mechanical ventilation, use of } \\
\text { glucocorticoids and anti viral drug remdesvir. }\end{array}$ & $\begin{array}{l}\text { Predisposing factors for co } \\
\text { infection of black fungus } \\
\text { with COVID were } \\
\text { highlighted }\end{array}$ \\
\hline $\begin{array}{l}\text { Verma DK, Bali RK. COVID-19 and } \\
\text { Mucormycosis of the Craniofacial } \\
\text { skeleton: Causal, Contributory or } \\
\text { Coincidental?J Maxfac Oral Surg. } \\
\text { 2021;20: } 165-66 . \\
\text { Doi: https://doi.org/10.1007/s12663- } \\
\text { 021-01547-8 }\end{array}$ & $\begin{array}{l}\text { Review } \\
\text { article }\end{array}$ & $\begin{array}{l}\text { Predisposing factors for any serious co infections in } \\
\text { COVID includes: } \\
\text { Prolonged and severe neutropenia } \\
\text { - Chemotherapeutic drugs, } \\
\text { - Immunosuppression, } \\
\text { Hematologic malignancies, } \\
\text { - Uncontrolled diabetes mellitus (DM), } \\
\text { Iron overload / deferoxamine therapy, } \\
\text { Prolonged corticosteroid use, } \\
\text { - Premature neonates, } \\
\text { - Intravenous drug use, } \\
\text { Malnutrition, major trauma or burns, and impending } \\
\text { nosocomial sources. }\end{array}$ & $\begin{array}{l}\text { Predisposing factors for } \\
\text { certain coinfections in } \\
\text { COVID were highlighted }\end{array}$ \\
\hline $\begin{array}{l}\text { 4. Garg D, Muthu V, Sehgal IS, } \\
\text { Ramachandran R, Kaur H, Bhalla A, } \\
\text { etal. Coronavirus Disease (Covid-19) } \\
\text { Associated Mucormycosis (CAM): } \\
\text { Systematic Review of Literature. } \\
\text { Mycopathologia. 2021; 186(2): 289-298. } \\
\text { Doi: } 10.1007 / \mathrm{s} 11046-021-00528-2\end{array}$ & $\begin{array}{l}\text { Systematic } \\
\text { review }\end{array}$ & $\begin{array}{l}\text { Supportive care for COVID along with management } \\
\text { of black fungus, co infections can be helpful to } \\
\text { reduce the mortality rate } \\
\text { Fungal cultures, direct staining of sample, Enzyme } \\
\text { Linked Immunosorbent Assays (ELISA), and PCR } \\
\text { can be used for diagnosis of mucormycosis }\end{array}$ & $\begin{array}{l}\text { Necessity of reviewing } \\
\text { COVID management } \\
\text { guidelines by giving } \\
\text { significance to co infections }\end{array}$ \\
\hline $\begin{array}{l}\text { 5. Chen N, Zhou M, Dong X. } \\
\text { Epidemiological and clinical } \\
\text { characteristics of } 99 \text { cases of } 2019 \text { novel } \\
\text { coronavirus pneumonia in Wuhan, } \\
\text { China: a descriptive study. Lancet. }\end{array}$ & $\begin{array}{l}\text { Original } \\
\text { article }\end{array}$ & $\begin{array}{l}\text { Early case case recognition and prompt management } \\
\text { of black fungu scan reduce mortality in COVID } \\
\text { Combination of systemic anti fungals and surgical } \\
\text { debridement can improve treatment outcomes }\end{array}$ & $\begin{array}{l}\text { Management of blackfungus } \\
\text { in COVID I shighlighted }\end{array}$ \\
\hline
\end{tabular}




\begin{tabular}{|c|c|c|}
\hline $\begin{array}{c}\text { 2020; 395:507-513. Doi: } \\
\text { https://doi.org/10.1016/ S0140- } \\
6736(20) 30211-7^{9}\end{array}$ & $\bullet \quad \begin{array}{c}\text { Intra venous (I/V) amphotericin B is the } \\
\text { recommended drug of choice }\end{array}$ \\
$\begin{array}{c}\text { While intraorbital irrigation with amphotericin will be } \\
\text { helpful for spreading craniofacial infection. }\end{array}$
\end{tabular}

Table I: Salient Features for 05 Selected Articles after Critical appraisal

COVID 19 infection, is believed to have strong association with immunodeficiency. COVID symptoms can range from subclinical, or asymptomatic to extremely severe with high mortality rate. The worsening of scenario arises when triad of underlying severity of immunodeficiency, along with complicated COVID and overlaid bacterial, or fungal infections arises. A Black fungus or Mucormycosis is one of the common and life threatening fungal infection. It is caused by eiher Rhizopus or Mucor species belonging to a group of Mucoromycotina. Many Indian studies are highlighting its association with COVID, in both acute phase and even recovered patients. A key factor for correlation amongst COVID-19 and mucormycosis is the decreased cluster differentiation 4 and 8 positive T-helper (CD4+ T and $\mathrm{CD} 8+\mathrm{T})$ cell counts. Though supplemented factors includes prolong hospital stays especially in ICUs, mechanical ventilation, use of steroids, anti-viral drug i.e remdesvir, and above all use of life saving immunomodulatory drug i.e tocilizumab. None of these can be avoided for COVID management. The risks and benefits used to be weighed for every choice of management. Though so far in Pakistan very few cases of black fungus are reported, but yet truly a threat for worsening situation can be there. Therefore, besides vigilant approach by health care workers, the community should be well aware from this coexisting condition [6, 7].

'Black fungus' is called as such because of specific pathogenesis events, which results in blackening of involved cells and tissues. This fungal infection can be acquired by inhalation of fungal spores from air or direct inoculation into ulcerated skin or inner layers of gastrointestinal. After entering into body the fungi destroys blood vessels, and penetrates into deeper layers of body, ultimately enters the bones. The infection usually spreads to the facial sinuses, eye orbits, layers of brain, and brain itself, within 03 days to 04 weeks' time, the reported mortality rate ranges between $50 \%$ - $80 \%$ especially for the intraorbital or intracranial complications [8].

In view of seriousness of Black fungus infection, recognizing red flags for assessing the severity of illness harbors great significance. They can be in form of sinus pain, nasal stuffiness, black or bloody nasal discharge, persistent headache, fever, double vision, blurring of vision, abnormal bulging of eye balls, jaw or dental pain, non-healing ulcers of the palate, any neurological deficit, or infection of facial of skull bones. Presence of any of these symptoms must be taken care by consulting the physician. The diagnosis can easily be established by taking nasal swabs, samples from effected tissue, or tissue biopsy. The usually available tests includes staining of sample by potassium hydroxide or periodic acid Schiff, fungal cultures, ELISA and PCR studies. CT scan and MRI will be helpful to identify the extent of 'black fungus' infection. As soon the diagnosis confirms, aggressive management options with combination of injectable anti-fungal and surgical debridement should be used to stop the spread of infection [9-11].

Though for super added bacterial infections, antibiotics are usually given to COVID patients. But fungal infection in same manner necessitate attention. A vigilant approach for early assessing the symptoms, early case recognition by clinicians and timely management of 'black fungus' or mucormycosis is the only way out to combat this dangerous coinfection. The health care policy makers should provide updated protocols for this co existing infection. This will be helpful to reduce the miseries of COVID patients.

\section{Conclusion}

It is concluded that immunosuppression, anti virals, prolong hospital stay, use of tocilizumab and steroids as management of COVID predisposes to black fungus. Timely diagnosis and use of systematic anti fungals can reduce mortality rate form this co infection.

\section{Recommendations}

1. It is recommended that patients having symptoms of black fungus in COVID patients should be immediately worked up for confirmation of diagnosis.

2. The fungal culture and sensitivity imparts great significance but time consuming tests, so should be on second thought for diagnosis.

3. Confirmation of Mucor or Rhizopus species, as etiological factor for mucormycosis should be done by PCR. Which though costly but accurate and results can also be obtained earlier.

4. Radiological investigations like CT scan or MRI can be supportive ones to see the extent of spread of infection.

5. Till the confirmation by lab or radiological tests, management can be started by broad spectrum systemic anti-fungal.

6. The large scale studies are required to see comparative association of various tests and anti-fungal to appropriately and timely management of this lethal co infection.

\section{Limitation of study}

1. Small sample size

2. Editorials, letter to editor, case reports, commentary, case series report and short communications were not included for this systematic review.

\section{References}

1. Chennamchetty VK, Adimulapu S, Kola BP, Padua MD, Ambika C, Verma MK, etal. (2021) Post-COVID pulmonary mucormycosis- A case report. IP Ind J Immunol Resp Med; 6(1): 62-66.

2. Khudyakov A, Ahmed R, Huynh CD, Dehghani A, Li Z, Rose M, etal. (2021) A rare indolent course of rhinocerebral mucormycosis. Case Reports Infect Dis;43812541:5

3. Skiada A, Floerl CL, Klimko N, Ibrahim A, Roilides E, Petrikkos G, etal. (2018) Challenges in the diagnosis and treatment of mucormycosis. Med Mycol; 56(1): 93-101.

4. Sarkar S, Gokhale T, Choudhury SS, Deb AK. (2021) COVID19 and orbital mucormycosis. Indian $\mathrm{J}$ Ophthalmol; 69(4):1002-1004.

5. PRISMA Guidelines.

6. Verma DK, Bali RK. (2021) COVID-19 and Mucormycosis of the Craniofacial skeleton: Causal, Contributory or Coincidental?J Maxfac Oral Surg;20: 165-66.

7. Leon CDE, Hernandez CLD, Zulueta RP, Walsh TJ. (2017) Diabetes mellitus as the major risk factor for mucormycosis in Mexico: epidemiology, diagnosis, and outcomes of reported cases. Med Mycol. 
8. Khatri A, Chang KM, Berlinrut I, Wallach F. (2021) Mucormycosis after Coronavirus disease 2019 infection in a heart transplant recipient - Case report and review of literature. J Mycol Med; 31(2): 101125.

9. Chen N, Zhou M, Dong X. (2020) Epidemiological and clinical characteristics of 99 cases of 2019 novel coronavirus pneumonia in Wuhan, China: a descriptive study. Lancet. 395:507-513.

10. Garg D, Muthu V, Sehgal IS, Ramachandran R, Kaur H, Bhalla A, etal. (2021) Coronavirus Disease (Covid-19) Associated
Mucormycosis (CAM): Case Report and Systematic Review of Literature. Mycopathologia; 186(2): 289-298.

11. Floerl CL, Klimko N, Ibrahim A, Roilides E, Petrikkos G. (2018) Challenges in the diagnosis and treatment of mucormycosisMed Mycol. 56(1): 93-101.

12. Fekkar A, Lampros A, Mayaux J, Poignon C, Demeret S, Constantin JM, etal. (2021) Occurrence of Invasive Pulmonary Fungal Infections in Patients with Severe COVID-19 Admitted to the ICU. Am J Respir Crit Care Med. 203(3): 307-317.

13. Li Z, Lu G, Meng G. (2019) Pathogenic Fungal Infection in the Lung. Front Immunol. 10: 1524.
This work is licensed under Creative Commons Attribution 4.0 License
Ready to submit your research? Choose Auctores and benefit from:

* fast, convenient online submission

* rigorous peer review by experienced research in your field

* rapid publication on acceptance

* authors retain copyrights

* unique DOI for all articles

* immediate, unrestricted online access

At Auctores, research is always in progress.

Learn more auctoresonline.org/journals/clinical-research-and-clinicaltrials 